\title{
ASESMEN KOGNITIF DAN PSIKOMOTOR BERBANTUAN TRAINER KIT TUBE IN TUBE HEAT EXCHANGER PADA MATA PELAJARAN SISTEM INSTALASI REFRIGERASI BAGI SISWA SMK TPTU
}

\author{
Iskandar Dzulkarnaen', Wahid Munawar', Ega T. Berman³ \\ Universitas Pendidikan Indonesia \\ Jl. Dr. Setiabudhi No. 229 Bandung 40154 \\ iskandardz18@gmail.com
}

\begin{abstract}
ABSTRAK
Penelitian ini bertujuan untuk membuat alat tes untuk dapat mengukur hasil pembelajaran kognitif dan psikomotor pada siswa secara baik. Metode penelitian ini menggunakan metode penelitian dan pengembangan. Responden penelitiaan yaitu siswa SMK TPTU kelas 2. Asesmen yang disusun pada mata pelajaran sistem instalasi refrigerasi. Tahap penelitian ini diantaranya: 1) pengumpulan data; 2) membuat kisi-kisi soal berdasarkan silabus; 3) pembuatan simulator; 4) validasi instrument; 5) melakukan uji ketercapaian produk; 6) analisi data dan menarik kesimpulan. Hasil penelitian diperoleh asesmen kognitif yang telah tervalidasi isi dan konstruk sebanyak 21 butir soal dan tes kinerja yang telah di validasi isi sebanyak 48 butir jobsheet. Hasil uji coba produk kepada siswa yaitu rata-rata tes kognitif siswa memperoleh nilai 83,5, sedangkan untuk tes kinerja diperoleh rata-rata 83,5. Kesimpulan yaitu asesmen yang baik dapat meningkatkan hasil belajar dan lebih efektif.
\end{abstract}

Kata kunci: asesmen mata pelajaran, sistem instalasi refrigerasi, heat exchanger

\section{PENDAHULUAN}

Pendidikan merupakan cara untuk mencerdaskan bangsa yang sesuai dengan pembukaan Undang Undang Dasar 1945 alinea ke-4 serta ingin mencapai tujuan pendidikan nasional. Perkembangan jaman saat ini menuntut adanya sumber daya manusia yang berkualitas sehingga mampu bersaing dengan negara lain yang telah maju. Pendidikan mempunyai peranan yang sangat penting dalam menciptakan sumber daya manusia yang berkualitas. Pendidikan yang berkualitas akan berpengaruh pada kemajuan diberbagai bidang.

Di samping mengusahakan pendidikan yang berkualitas, pemerintah perlu melakukan pemerataan pendidikan dasar bagi setiap warga negara Indonesia. Hal tersebut agar mampu berperanserta dalam memajukan kehidupan bangsa. Pendidikan merupakan salah satu sektor yang paling penting dalam pembangunan nasional. Hal ini karena melalui pendidikan dapat dibentuk manusia yang berkualitas. Pendidikan nasional berfungsi mengembangkan kemampuan dan membentuk watak seperti peradaban bangsa yang bermartabat dalam rangka mencerdaskan kehidupan bangsa, bertujuan untuk

\footnotetext{
${ }^{1}$ Mahasiswa Departemen Pendidikan Teknik Mesin FPTK UPI

2 Dosen Departemen Pendidikan Teknik Mesin FPTK UPI

${ }^{3}$ Dosen Departemen Pendidikan Teknik Mesin FPTK UPI
} 
mengembangkan potensi peserta didik agar menjadi manusia yang beriman dan bertaqwa kepada Tuhan Yang Maha Esa, berakhlak mulia, sehat, berilmu, cakap, kreatif, mandiri, menjadi warga negara yang demokratis serta bertanggung jawab.

Pada dasarnya kegiatan pembelajaran yang dilakukan dewasa ini dibagi menjadi 3 bagian pokok, yaitu kognitif (pemahaman), psikomotor (kinerja) dan afektif (sikap). Masing-masing bagian memiliki batasannya penilaian tersendiri. Setiap mata pelajaran pada umumnya mengandung 3 bagian tersebut, khusus untuk bagian afektif dapat diterapkan langsung pada bagian kognitif dan psikomotor. Kegiatan pembelajaran pada tingkat SD, SMP, SMA/SMK tidak dapat terlepas dari penilaian (Primadiana dan Suyata, 2013). Sebagai bahan penilaian ketiga aspek tersebut semestinya memiliki variabel penilaian yang berbeda satu dengan yang lainnya, sehingga kemampuan peserta didik dalam menangkap pembelajaran yang diberikan guru dapat diukur dengan lebih terarah (Arikunto, 2012). Terutama pada tes kinerja yang menjadi patokan keberhasilan siswa tingkat SMK. Penilaian adalah kegiatan yang sistematis dalam mengumpulkan informasi tentang proses dan hasil belajar peserta didik dalam rangka pengambilan keputusan berdasarkan kriteria dan pertimbangan tertentu (Thiagarajan, et. al., 1984).

Asesmen atau penilaian (assessment) sebagai penilaian proses, kemajuan, dan hasil belajar siswa (outcomes) (Stiggins, 2004). Penilaian kinerja semakin populer karena menggabungkan pembelajaran dan penilaian. Siswa belajar ketika mereka bekerja pada penilaian kinerja, seperti periode pengujian tradisional di mana mereka sering belajar apa pun. Penilaian otentik memiliki keuntungan tambahan memberikan situasi belajar siswa yang realistis. Dimana mereka memecahkan masalah berantakan di dunia nyata, dengan banyak jawaban diterima, bukan masalah palsu yang hanya ada satu jawaban yang benar (Sofyan, 2006).

Hasil wawancara dengan salah satu staf pengajar di SMKN 1 Cimahi diperoleh kesimpulan bahwa pada kenyataannya hanya sedikit sekolah yang menerapkan ketiga penilaian secara terpisah. Sebagian besar sekolah hanya menerapkan tes kognitif sebagai patokan kelulusan tes psikomorik dan afektif, bahkan tak sedikit yang mengabaikan tes afektif pada format penilaian (Daryanto, 2007). Selain itu, salah satu permasalahan tidak adanya tes kinerja adalah keterbatasan alat dan bahan, sehingga sangat perlu bagi sekolah memiliki trainer kit sebagai salah satu alat penunjang tes kinerja yang akan digunakan di sekolah. 
Pada umumnya trainer kit refrigerasi tidak menggunakan heat exchanger, sehingga penulis merancang trainer kit refrigerasi dengan tambahan heat exchanger guna memberikan siswa pengetahuan baru antara perbedaan siklus refrigerasi pada umumnya dengan siklus refrigerasi dengan tambahan heat exhanger.

\section{METODE PENELITIAN}

Jenis penelitian yang digunakan dalam penelitian ini adalah penelitian dan pengembangan. Metode penelitian ini digunakan untuk menghasilkan produk asesmen dan menyempurnakan produk yang telah ada serta menguji keefektifan produk tersebut. Pengembangan yang digunakan yaitu alur pengembangan 4-D dengan tahapan utama yaitu define, design, develop, dan disseminate dan telah dimodifikasi, secara garis besar langkah penelitian dan pengembangan. Langkah penelitian yang dimodifikasi tersebut terdiri dari tiga tahap yaitu: studi pendahuluan, pengembangan model yang meliputi uji coba dengan sampel terbatas (uji coba terbatas) dan uji coba dengan sampel lebih luas (uji coba lebih luas), dan uji model yang meliputi uji produk melalui eksperimen dan sosialisasi produk.

\section{HASIL PENELITIAN}

Pada setiap tes kinerja yang dilakukan, selalu diberikan stimulus kepada siswa sehingga siswa dapat memberikan berbagai respon yang positif. Tahapan perencanaan adalah tahapan pembuatan trainer unit refrigerasi dengan tube in tube heat exchanger (Gambar 1) yang dilakukan di Workshop refrigerasi dan Tata Udara (RTU) DPTM FPTK UPI.

Tes pengetahuan atau tes kognitif ini berupa soal pilihan ganda dengan jumlah soal 25 butir dengan pembagian 25 pilihan ganda. Analisis uji validitas isi menggunakan CVR. Uji validitas isi berdasarkan atas judgment ahli, yang mana butir soal tersebut dianggap penting atau tidak penting. Validator menyatakan $96 \%$ butir soal tersebut dianggap penting sedangkan $4 \%$ atau hanya 1 soal yang tidak penting. Uji keterbacaan sebagai salah satu bagian dari validitas isi menyatakan hasil penelitian bahwa 100\% soal dapat dipahami. Butir soal yang tidak dipahami kemudian diperbaiki sesuai dengan saran validator baik dari segi bahasa, isi, dan kesesuaian antara soal dan indikator sebelum dilakukan uji validitas konstruk. 


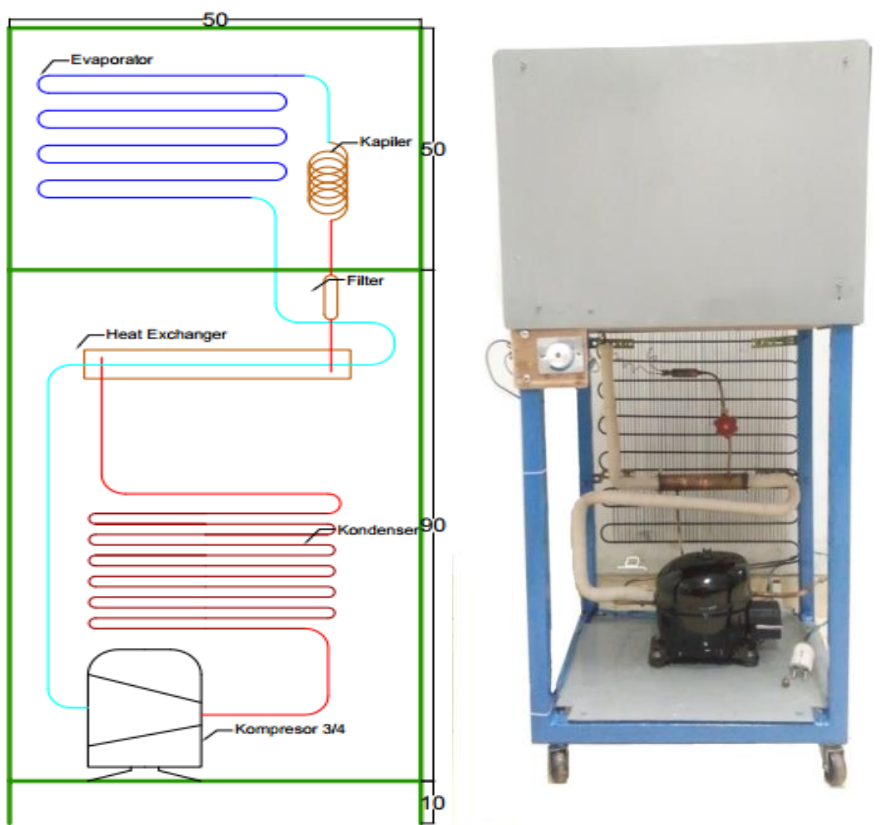

Gambar 1. Trainer kit tube in tube heat exchanger (Sumber: Dokumen pribadi)

Validitas konstruk terdiri atas tingkat kesukaran, daya pembeda, indeks pengecoh. Analisis validitas konstruk dilakukan dengan menggunakan program Anates. Uji validitas konstruk dimaksudkan untuk mengetahui kualitas butir soal dan sebagai kelayakan alat tes. Sehingga dengan alat tes yang valid dapat mengukur peningkatan hasil belajar siswa.

Uji tingkat kesukaran yang dimiliki soal tersebut yaitu 10 butir soal (40\%) sangat mudah, 2 butir soal (8\%) mudah, 10 butir soal (40\%) sedang, 2 butir soal (8\%) sukar dan 1 butir (4\%) sangat sukar. Hasil analisis daya pembeda butir soal terdapat 8 butir soal (32\%) sangat baik, 13 butir soal (54\%) baik, dan 4 butir soal (16\%) jelek. Hasil penelitian terkait dengan pengecoh menunjukkan bahwa dari 40 butir soal kategori sangat baik, 2 butir soal (5\%) berfungsi baik, 3 butir soal (7,5\%), berfungsi cukup 12 butir soal (30\%), berfungsi kurang baik 9 butir soal (22,5\%), dan berfungsi tidak baik/jelek 14 butir soal (35\%). Hasil uji reliabilitas soal sebesar 0,89 dalam kategori tinggi.

Uji validitas rasio dilakukan menggunakan pendekatan CVR. Expert judgement dilakukan untuk tes kognitif terdiri dari 3 orang guru SMK TPTU. Tes kinerja terdiri dari dua orang teknisi dan tiga orang guru yaitu: Sedangkan uji keterbacaan dilakukan oleh lima orang mahasiswa RTU. Total butir indikator tes uji kinerja kompetensi evakuasi dan pengisian pada unit refrigerasi adalah 48 item, terdapat 45 item penting (valid) dan 3 item tidak penting (tidak valid) dari hasil judgement ahli. Untuk hasil uji keterbacaan didapat 4 
item dari 48 item indikator pekerjaan tidak sesuai . Sebagian item dibuang dan sebagian item yang tidak sesuai kemudian di perbaiki agar untuk uji ketercapaian produk dapat dilakukan.

Perhitungan validitas isi yang dikembangkan Lawshe dikenal dengan Content Validity Ratio (CVR) (Primardiana, et.al., 2013). Hasil validitas isi yang terdiri dari expert judgment dan tes keterbacaan untuk tes kognitif terdapat $96 \%$ soal yang dinyatakan valid. Sedangkan untuk tes kinerja dibagi menjadi 2 pembahasan, yaitu proses charging refrigerant dan evakuasi refrigerant. Hasil validasi menunjukkan pada jobsheet charging refrigerant 93,75\% valid dan untuk jobsheet evakuasi refrigerant $91 \%$ valid. Butir soal yang memiliki validitas yang tinggi mencerminkan soal tersebut telah memiliki kehandalan dan tidak perlu diragukan ketepatannya dalam mengukur kemampuan peserta didik (Sudijono, (2011). Butir soal yang memiliki validitas yang rendah mencerminkan soal tersebut tidak valid sehingga perlu dilakukan tindakan terhadap soal tersebut.

Instrumen dilakukan uji validitas indeks menggunakan perhitungan CVI (jumlah CVR/jumlah item). Uji validitas judgement ahli didapat total nilai CVR sebesar 45 dari 48 item yang berarti jumlah nilai CVI adalah 0, (sangat valid). Uji keterbacaan total nilai CVR sebesar 44 dari 48 item yang berarti jumlah nilai CVI adalah 0,91 (sangat valid). Setelah uji validitas indeks dilakukan dan hasilnya valid maka dapat dilakukan uji validitas tes keterampilan.

\section{PEMBAHASAN}

Refleksi desain produk dilakukan dengan cara menganalisis secara bersama-bersama karakteristik penilaian butir soal (validitas, tingkat kesukaran, daya pembeda, dan indeks pengecoh). Ada tiga kategori yaitu baik, kurang baik, dan tidak baik/jelek. Data yang didapatkan ada 4 soal yang tidak cocok digunakan menjadi alat tes kognitif dan lebih baik dibuang. sehingga terdapat 21 soal yang cocok digunakan menjadi alat tes kognitif. Diketahui penyebab kegagalan butir soal yang pertama terletak pada validasi butir soal oleh expert judgment yang menyatakan bahwa butir soal no 25 dunyatakan tidak penting untuk dimasukan ke dalam alat tes.

Penyebab kegagalan kedua terletak pada indeks pengecoh yang tidak berfungsi. Hal ini menandakan pengecoh tidak menarik perhatian peserta tes, sehingga terjadi kecenderungan banyak siswa yang tidak memilih distraktor. Kegagalan yang terakhir terletak pada daya pembeda soal yang berarti ketidakmampuan butir soal dalam membedakan siswa yang sudah menguasai materi dengan yang belum menguasai materi 
pembelajaran. Hal tersebut menunjukkan bahwa butir soal belum memiliki dukungan besar terhadap skor total tes (Trianto, 2014). Sedangkan hasil penelitian (validasi) pada instrument tes psikomotor/kinerja terdapat 3 butir job sheet yang tidak dinyatakan valid sehingga lebih baik dibuang.

Validitas tes adalah derajat fungsi pengukurnya suatu tes, atau derajat tepatan ukurnya sesuatu tes (Suryabrata, 2000). Validitas suatu tes mempermasalahkan apakah tes tersebut benar-benar mengukur apa yang hendak diukur. Maksudnya apakah suatu tes mampu mengungkapkan dengan tepat ciri atau keadaan yang sesungguhnya dari obyek ukur. Hal tersebut akan tergantung dari tingkat validitas tes, validitas konstruk dibagi menjadi 3 pembahasan, yaitu daya pembeda, indeks pengecoh dan tingkat kesukaran. Analisis soal secara keseluruhan dapat dilihat berdasarkan indeks reliabilitas soal. Reliabilitas soal adalah tingkat atau derajat konsistensi dari suatu instrumen untuk mengukur sehingga dapat dipercaya. Hasil penelitian menunjukkan bahwa soal tes kognitif memiliki indeks reliabilitas sebesar 0,89 atau 89\%. Hasil tersebut menunjukkan bahwa masing-masing seri soal memiliki koefisien reliabilitas yang berbeda dengan tingkat reliabilitas yang sama yaitu memiliki reliabilitas yang tinggi. Reliabilitas soal $\geq 0,70$ artinya soal memiliki reliabilitas yang tinggi, tetapi apabila reliabilitas soal $<0,70$ reliabilitas soal tersebut rendah atau tidak reliabel (Sudijono, 2011).

Hasil penelitian menunjukkan tingkat kesukaran yang dimiliki soal tersebut yaitu 10 butir soal (40\%) sangat mudah, 2 butir soal (8\%) mudah, 10 butir soal (40\%) sedang, 2 butir soal (8\%) sukar dan 1 butir (4\%) sukar. Bermutu atau tidaknya butir item tes hasil belajar dapat diketahui dari tingkat kesukaran butir tes tersebut. Salah satu analisis yang harus dilakukan untuk mengetahui apakah butir soal dapat dikatakan baik sebagai alat evaluasi adalah analisis terhadap tingkat kesukaran. Tingkat kesukaran butir soal tidaklah menunjukkan bahwa butir soal itu baik atau tidak (Zainul, 2013). Tingkat kesukaran butir hanya menunjukkan bahwa butir soal itu sukar atau mudah untuk kelompok peserta tes tertentu. Butir soal hasil belajar yang terlalu sukar atau terlalu mudah tidak banyak memberi informasi tentang butir soal atau peserta tes.

Hasil analisis daya pembeda butir soal, 8 butir soal (32\%) sangat baik, 13 butir soal (54\%) dengan baik, dan 4 butir soal (16\%) dengan jelek. Daya pembeda item sangat penting. Salah satu dasar menyusun butir tes hasil belajar adalah adanya anggapan bahwa kemampuan antara peserta didik adalah berbeda. Soal yang didominasi butir-butir soal dengan daya pembeda yang tidak berfungsi dengan baik menyebabkan peserta didik dengan 
kemampuan rendah dapat menjawab dengan benar sedangkan peserta didik yang berkemampuan tinggi menjawab salah. Daya pembeda soal dapat digunakan untuk meningkatkan kualitas soal berdasarkan data empirik dari analisis butir. Indeks daya beda dapat menunjukkan apakah soal tersebut baik, direvisi, atau ditolak.

Hasil penelitian butir soal tes kognitif diperoleh indeks pengecoh sebagai berikut: kategori sangat baik 2 butir (5\%), berfungsi baik 3 butir (7,5\%), berfungsi cukup 12 butir (30\%), berfungsi kurang baik 9 butir (22,5\%), dan berfungsi tidak baik/jelek 14 butir (35\%). Pengecoh dapat dikatakan berfungsi dengan baik jika paling sedikit dipilih oleh 5\% pengikut tes. Besarnya persentase butir soal dengan kualitas pengecoh yang kurang baik mengidentifikasi bahwa pengecoh belum dapat berfungsi dengan baik. Pengecoh terlalu mencolok, menyesatkan, dan cenderung heterogen. Pengecoh tersebut tidak memiliki daya tarik yang besar bagi peserta tes yang kurang memahami konsep atau kurang menguasai materi mata pelajan.

\section{KESIMPULAN}

Ases pada yang dilakukan dengan bantuan trainer tube in tube heat exchanger mampu mengukur hasil belajat dengan akurat. Setiap aspek yang diukur sudah sesuai dengan kompetensi yang dipersyaratkan. Asesmen dilakukan dengan memiliki keakuratan, ketepatan, keterbacaan, dan kesesuaian dengan apa yang diukurnya secara baik.

\section{REFERENSI}

Arikunto, S. (2012). Dasar-dasar Evaluasi Pendidikan. Jakarta: Bumi Aksara.

Daryanto. (2007). Evaluasi Pendidikan. Jakarta: PT Rineka Cipta.

Primadiana. H. dan Suyata, S. (2013). Model Evaluasi Pembelajaran Berbasis Kaizen Di Sekolah Menengah Atas. Jurnal Penelitian dan Evaluasi Pendidikan 17(2), 318332.

Sofyan, A. (2006). Evaluasi Pembelajaran IPA Berbasis Kompetensi. Jakarta: Lembaga Penelitian UIN Jakarta.

Stiggins, J. R. (2004). Student Centered Classroom Assesment. NewYork: MacMilan College Publishing Company.

Sudijono, A. (2011). Pengantar Evaluasi Pendidikan. Jakarta: Raja Grafindo Persada. 
Thiagarajan, S., Semmel, D. S, and Semmel, M. I. (1984). Instructional Development for Training Teachers of Exceptional Children: A Sourcebook. Indiana: Indiana University.

Trianto. (2014). Mendesain Model Pembelajaran Inovatif, Progresif, dan Kontekstual. Jakarta: Prenadamedia Group.

Zainul, A. (2013). Evaluasi Pembelajaran. Bandung: Remaja Rosdakarya. 